\title{
Ecological Hazards of Some Pesticides on Unicellular Freshwater Green Alga; Pseudokirchneriella subcapitata
}

\begin{abstract}
Salwa M. Abd-Allah ${ }^{1}$, Neama A
ABSTRACT

Aquatic toxicity and differential sensitivity of different pesticide categories on freshwater green alga; Pseudokirchneriella subcapitata were investigated. In this context, growth-inhibiting tests of 14 pesticides (including 4 fungicides; 4 acaricides/ nematicides and 6 insecticides) were carried out. Based on $\mathrm{IC}_{50}$ values, $P$. subcapitata was more sensitive to many pesticides (mostly fungicides and acaricides/ nematicides) and less sensitive to insecticides. The test alga was tolerant to carbendazim, while it was highly susceptible to prochloraz. The $96-\mathrm{h} \mathrm{IC}_{50}$ values for imidazole and benzimidazole fungicides; prochloraz and thiallophanate-methyl varied around 0.26 and $80.81 \mathrm{mg} / \mathrm{L}$; respectively, while organophosphates (chlorpyrifos-methyl, chlorpyrifos, profenofos, fenamifos, malathion and dimethoate) varied in their toxicities from 1.01 to 42.67 mg/L. Furthermore, carbamates (mancozeb, methomyl, carbosulfan and carbendazim) showed different patterns of $\mathrm{IC}_{50} \mathrm{~S}(\mathbf{0 . 2 7}, \mathbf{7 2 . 9 6}, 246.06$ and $393.26 \mathrm{mg} / \mathrm{L}$; respectively). According to estimated risk phrases, the decreasing order of the potential aquatic ecosystem risk imposed by the tested pesticides was prochloraz $>$ mancozeb+metalaxyl > chlorpyrifos-methyl $>$ chlorpyrifos $>$ imidaclopride > profenofos $>$ fenamifos $>$ malathion $>$ dimethoate > methomyl $>$ thiallophanate-methyl $>$ carbosulfan $>$ mineral oil > carbendazim. In conclusion, the results of this study clearly emphasize the importance of estimating risk phrases when assessing the pesticide stress on aquatic ecosystems and indicated that the tested pollutants may imbalance the aquatic ecosystem and cause a shift of algal species dominance. Such speculations need further more studies to fully understand the processes involved in pesticide toxicity.
\end{abstract}

Key words: pesticides, toxicity, green algae, risk phrases. Corresponding author: Sabdallah@link.net

\section{INTRODUCTION}

The environment is currently changing worldwide, and ecosystems are being exposed to multiple anthropogenic pressures. Understanding and consideration of such environmental conditions is required in ecological risk assessment of toxicants, but it remains basically limited (Stampfli et al., 2011). The relatively fast degradation rate of pesticides used nowadays may be taken as an argument for a low risk of ecological damage resulting from pesticide

\footnotetext{
${ }^{1}$ Mammalian and Aquatic Toxicity Dept., Central Lab of Agricultural Pesticides, Agricultural Research Center, Alexandria, Egypt.

${ }^{2}$ Pesticide Chemistry and Toxicology Dept., Faculty of Agriculture

(Fuka Branch)Alexandria University, Marsa Matrouh, Egypt.

Received February15, 2012, Accepted March 28, 2012
}

contamination of aquatic ecosystems. Although the duration of the pesticide peak may be brief, exposure can result in reduced survival, growth, and/or reproduction of susceptible species. These acute effects may be extensive enough to produce further changes in interactions between species not directly susceptible. Pesticide exposure can ultimately produce fundamental shifts at structural and functional levels of the receiving ecosystem due to a combination of direct and indirect effects, which may also persist when the pesticide has been degraded. Several studies have documented an increased algal biomass in aquatic ecosystems following exposure to insecticides (Brock et al., 2000). This is most likely caused indirectly by insecticide exposure and induced by a decrease in zooplankton algal grazing (Crossland, 1984; Van den-Brink et al., 1995). Increase in the algal biomass can shade macrophytes, thereby reducing their growth (Sand-Jensen and Borum, 1991; Brock et al., 2000). Thus, via secondary effects, pesticide exposure may alter the structure of receiving ecosystems and possibly induce a shift from a macrophyte dominated to an algal-dominated ecosystem.

Algae are composing the primary producer level in providing the energy that sustains invertebrates and fish in most aquatic ecosystems. The action of toxic substances on algae is therefore not only important for the organisms themselves, but also for other links in the food chain. Hence, their ecological position at the base of most aquatic food webs and their essential roles in nutrient cycling and oxygen production are critical to many ecosystems (Sabater and Carrasco, 2001). Green algae are known to be comparatively sensitive to many chemicals, they have been considered indicators of the bioactivity of industrial wastes and they vary in their response to a variety of toxicants (Real et al., 2003).

Algal toxicity tests are considered relatively sensitive bioassay tools against different chemical substances and are increasingly being used in bioassay test batteries for environmental management of chemical discharges. Pseudokirchneriella subcapitata (formerly Selenastrum capricornutum) is an unicellular chlorophyceae algae that was widely used in studies of pollutants effects (Walsh and Merril, 1984; Jonsson et al., 1998; Weyers 
and Vollmer, 2000 and Okamura et al., 2002) and recommended by regulatory national (Jonsson and Maia, 1999) and international (OECD, 1984; U.S. EPA, 1994) agencies as a test organism. A wide range of effects may occur, from lethal (rapid death) to sublethal effects, or, in some cases, no effect may be seen at all (Moriarty, 1990). Sublethal effects can be seen in the inhibition of an organism's physiological functions such as feeding, growth and reproduction, or effects on its behavior, biochemical and histological functions. However, tests on single species of algae are of limited applicability in assessing the effects of environmental contaminants on algal communities, which are composed of an array of species with different sensitivities. Furthermore, organisms exposed to chemicals in their natural surroundings may be more (or less) sensitive to toxicants than organisms exposed in the laboratory, because of effects such as density dependence and stress induced by food shortage or competition.

Some reports on the comparative sensitivity of pesticides toward various green algae have been published (Ma et al., 2004a, b) and relatively few reports have been involved with differential response of various algal species to fungicides and acaricides (Faust et al., 2000; Ferrando et al., 1996). Thus, the current work was suggested to examine the effects of several pesticide categories that have been widely used in Egypt on the green alga, Pseudokirchneriella subcapitata and to compare its differential sensitivity against those pesticides.

\section{MATERIALS AND METHODS}

Chemicals: Tested compounds were obtained from the Central Lab. of pesticides; Agricultural Research Center, Ministry of Agriculture, Egypt. The chemical names are shown in Table (1).

\section{Test organism and culture conditions.}

The green alga Pseudokirchneriella subcapitata obtained from Faculty of Science; Mansoura University, Egypt was used as test organism. The stock culture was maintained according to U.S. EPA, 2002 and OECD, 2002 in $250 \mathrm{ml}$ borosilicate Erlenmeyer flasks containing culture medium at $24 \pm 2{ }^{\circ} \mathrm{C}$, under a continuous white fluorescent light of 3000-4000 lux and manually shake twice a day. Axenic culture was maintained in standard AAM nutrient media as described in Miller et al., 1978. Two $\mathrm{ml}$ of stock culture were weekly transferred into $100 \mathrm{ml}$ of new culture medium to maintain a continuous supply of "healthy" cells for the tests.

\section{Table 1. Selected pesticides and their chemical names}

\begin{tabular}{|c|c|c|}
\hline Pesticide & Formulation & Chemical name \\
\hline \multicolumn{3}{|l|}{ Fungicide } \\
\hline -Carbendazim & Kemazed; $50 \%$ SC & $\mathrm{N}$-(1H-benzimidazol-2-yl) carbamic acid methyl ester \\
\hline -Mancozeb+ metalaxyl & Redozed; 72\%WP & Manganese ethylenebis(dithiocarbamate)(polymeric)complex with zinc salt\& \\
\hline & & $\begin{array}{l}\text { Methyl N-(methoxyacetyl)-N-(2,6-xylyl)-DL-alaninate;Methyl2[(2,6- } \\
\text { dimethylphenylmethoxyacetyl)amino]propionate }\end{array}$ \\
\hline -Prochloraz & Master; 25\%EC & N-propyl-N-[2-(2,4,6-trichlorophenoxy)ethyl]-1H-imidazole-1-caboxamide(CA) \\
\hline -Thiallophanate-methyl & Hesta; 70\%WP & Dimethyl [(1,2-phenylene) bis(iminocarbonthioyl)] bis(carbamate) \\
\hline \multicolumn{3}{|l|}{ Acaricide/Nematicide } \\
\hline -Chlorpyrifos & Actaphos; $48 \% \mathrm{EC}$ & 0,0-diethyl 0-(3,5,6-trichloro-2-pyridinyl-phosphorothioate) \\
\hline -Chlorpyrifos-methyl & Actan; 50\%EC & 0,0-dimethyl 0-(3,5,6-trichloro-2-pyridinyl-phosphorothioate) \\
\hline -Fenamiphos & Fenatode; $10 \% \mathrm{GR}$ & Ethyl 4-methylthio-m-tolyl isopropylphosphoramidate \\
\hline -Profenofos & Actakron; $72 \% \mathrm{EC}$ & 0,4-bromo-2-chlorophenyl 0-ethyl S-propylphosphorothioate \\
\hline \multicolumn{3}{|l|}{ Insecticide } \\
\hline -Carbosulfan & Marsal; 25\%WP & 2,3-dihydro-2,2-dimethyl-7-benzofuranyl[(dibutylamino)thio] methyl carbamate \\
\hline -Dimethoate & Sidon, $40 \% \mathrm{EC}$ & 0,0-dimethyl S-(Z-(methylamino)-2-oxoethyl) phosphorodithioate \\
\hline -Imidaclopride & Imidazed; 20\%SE & $\mathrm{N}$-[1-(6-chloro-3-pyridyl)methyl)methyl]-4,5-dihydroimidazol-2-yl)nitramide \\
\hline -Methomyl & Ceraplex; 90\%SP & S-methyl N-[(methylcarbamoyl)oxy]-thioacetimidate \\
\hline -Mineral oil & Supercapl; 96\%EC & $\begin{array}{l}\text { Complex mixture of hydrocarbons whose molecules have } 15-50 \text { carbon atoms, } \\
\text { often contains low level of sulfur and nitrogen }\end{array}$ \\
\hline -Malathion & Malason; $1 \% \mathrm{D}$ & Diethyl(dimethoxyphosphinothioylthio)succinate \\
\hline
\end{tabular}




\section{Acute toxicity test}

Algal acute toxicity test was conducted using different concentrations of a pesticide in sterile algal AAM growth media. Tested concentrations of a pesticide were prepared from stock solutions on an arithmetic progression covering an expected range of toxicity from 0 to $90 \%$. The final volume of AAM medium containing tested chemical was $50 \mathrm{ml}$. An inoculum of exponentially-growing culture of $P$. subcapitata (harvested from 4-7 days stock culture) was prepared no more than 2-3 $\mathrm{hr}$ prior to beginning of the test. Initial cell density for the growth inhibition test was 10,000 cells $/ \mathrm{ml}$. Controls containing only growth medium and algae were included. The test vessels were incubated continuously in a temperature-controlled $\left(25^{\circ} \mathrm{C}\right)$ orbital shaker set at $100 \mathrm{rpm}$ under continuous illumination provided by white fluorescent lamps.

Zero-time begins when we inoculate the test flasks containing the media and the tested pesticide with the algal cells followed by incubation for $96 \mathrm{hr}$. At the end of $96 \mathrm{hr}$, the growth of the alga in terms of viable cell concentration was determined in a Neubaur hemocytometer using a phase contrast microscope (Megharaj et al., 1999) accompanied with measurement of change in $\mathrm{pH}$. Growth inhibition (biomass) of the alga was used as the end point in this bioassay. All assays were conducted in duplicate. The percent inhibition values calculated relative to growth in untreated controls were used to obtain the inhibitive concentration; $\mathrm{IC}_{50}$ (concentration inhibitory to $50 \%$ of growth).

\section{Statistical analysis}

The growth rates were calculated according to official guidelines (OECD, 2002). Percent of inhibition in algal growth (\% I) relative to growth in control systems were calculated and $\mathrm{EC}_{50}$ values and other statistical parameters were estimated using Probit analysis (Finney, 1971). Risk Phrase of the tested chemicals on algae based on $\mathrm{IC}_{50}$ value and according to EU classification (European Union Directive $67 / 548 / \mathrm{EEC}, 2011)$ was evaluated as illustrated in the following table:

Table 2. Risk phrases of different chemicals on algae

\begin{tabular}{cc}
\hline $\begin{array}{l}\text { Acute toxicity on algae } \\
\text { ( IC50, } \mathbf{~ m g / L , ~ 9 6 ~ h ) ~}\end{array}$ & Risk phrase \\
\hline$<0.1$ & $\mathrm{R} 50$ \\
\hline $0.1-1$ & $\mathrm{R} 50 / 53$ \\
\hline$\geq 1-10$ & $\mathrm{R} 51 / 53$ \\
\hline$\geq 10-100$ & $\mathrm{R} 52 / 53$ \\
\hline$>100$ & $\mathrm{R} 52$ \\
\hline
\end{tabular}

R50: very toxic, R51: toxic, R52: harmful, R53: may cause long-term adverse effects in the aquatic environment

\section{RESULTS}

Differential sensitivity: Acute toxicities of 14 pesticides to the green unicellular alga $P$. subcapitata are summarized in Table 3 . Wide variations occurred in response to the tested fungicides, acaricides, nematicides and insecticides among the same species of the green alga. The 96-h $\mathrm{IC}_{50}$ values of imidazole and benzimidazole fungicides; prochloraz and thiallophanate-methyl varied around 0.26 and 80.81 $\mathrm{mg} / \mathrm{L}$; respectively, while organophosphates (chlorpyrifos-methyl, chlorpyrifos, profenofos, fenamifos, malathion and dimethoate) varied in their toxicities on the test alga from 1.01 to $42.67 \mathrm{mg} / \mathrm{L}$. Imidaclopride as a neonicotinoid was very toxic to the test alga recording an $\mathrm{IC}_{50}$ of $2.71 \mathrm{mg} / \mathrm{L}$. Toxicity of carbamates including mancozeb, methomyl, carbosulfan and carbendazim showed different patterns of $\mathrm{IC}_{50} \mathrm{~S}$ (0.27, 72.96, 246.06 and $393.26 \mathrm{mg} / \mathrm{L}$; respectively). Accordingly, based on the magnitude of the $\mathrm{IC}_{50}$ values, $P$. subcapitata was more sensitive to many pesticides (mostly fungicides and acaricides/ nematicides) and less sensitive to insecticides. Data also exhibited that the test alga was tolerant to mineral oil and carbendazim, while it was highly susceptible to prochloraz and mancozeb. The decreasing order of the sensitivity to green alga was as follows: prochloraz > mancozeb+ metalaxyl > chlorpyrifos-methyl $>$ chlorpyrifos $>$ imidaclopride $>$ profenofos $>$ fenamifos $>$ malathion $>$ dimethoate $>$ methomyl > thiallophanate-methyl > carbosulfan > mineral oil $>$ carbendazim. Furthermore, Table 4 shows ranking of the tested pesticides based on their fold of toxicity and accordingly their estimated ecological risk phrases. Data disclosed that prochloraz and mancozeb+metalaxyl were highly toxic (1501 and 1441 fold of toxicity; respectively) and such toxicities on $P$. subcapitata represent the highest among all of the tested pesticides compared with carbosulfan and mineral oil (1.59 and 1.19 fold of toxicity; respectively).

\section{DISCUSSION}

Fourteen agricultural pollutants were tested in order to evaluate their acute toxicity on $P$. subcapitata. In this context, we performed a screening test with a wide range of chemicals including insecticides, fungicides, acaricides and nematicides. The results of this screening were analogous to other studies described in the literature and were valuable to deal with other similar chemicals agents.

Regarding fungicide toxicity, data disclosed that prochloraz and mancozeb+metalaxyl were highly toxic (1501 and 1441 fold of toxicity; respectively) and such toxicities on $P$. subcapitata represent the highest among 
Table 3. Differential Sensitivity of unicellular green alga P.subcapitata to different pesticides

\begin{tabular}{|c|c|c|c|c|c|}
\hline Pesticide & $\mathrm{IC}_{50}(\mathrm{mg} / \mathrm{L})$ & $\mathbf{C L}^{\mathbf{a}}$ & $V_{L^{b}}$ & $\mathbf{S}^{\mathbf{c}}$ & Regression equation \\
\hline $\begin{array}{l}\text { Fungicide } \\
\text {-Carbendazim }\end{array}$ & 393.3 & $(249.375-435.691)$ & 0.389 & 4.5 & $Y=-11.666+4.496 x$ \\
\hline -Mancozeb + metalaxyl & 0.273 & $(0.210-0.357)$ & 0.006 & 1.0 & $Y=0.567+1.007 X$ \\
\hline -Prochloraz & 0.262 & $(0.204-0.339)$ & 0.011 & 1.2 & $\mathrm{Y}=0.723+1.244 \mathrm{X}$ \\
\hline -Thiallophanate-methyl & 80.81 & (69.052- 94.603) & 0.006 & 2.1 & $Y=-3.921+2.055 \mathrm{X}$ \\
\hline $\begin{array}{l}\text { Acaricide/Nematicide } \\
\text {-Chlorpyrifos }\end{array}$ & 1.210 & $(0.495-3.396)$ & 0.001 & 0.3 & $Y=0.838+0.272 \mathrm{X}$ \\
\hline -Chlorpyrifos-methyl & 1.005 & $(0.481-2.276)$ & 0.001 & 0.3 & $Y=0.924+0.308 X$ \\
\hline -Fenamiphos & 18.74 & $(14.555-24.463)$ & 0.005 & 0.9 & $Y=-1.267+0.995 X$ \\
\hline -Profenofos & 3.392 & $(2.585-4.589)$ & 0.008 & 0.9 & $Y=0.510+0.961 X$ \\
\hline $\begin{array}{l}\text { Insecticide } \\
\text {-Carbosulfan }\end{array}$ & 246.1 & $(193.515-313.341)$ & 0.004 & 0.9 & $Y=-2.274+0.951 \mathrm{X}$ \\
\hline -Dimethoate & 42.67 & $(28.404-67.025)$ & 0.004 & 0.8 & $Y=-1.279+0.785 X$ \\
\hline -Imidaclopride & 2.714 & $(2.206-3.413)$ & 0.008 & 1.2 & $Y=-0.507+1.168 \mathrm{X}$ \\
\hline -Methomyl & 72.96 & $(52.471-102.753)$ & 0.005 & 0.9 & $Y=-1.644+0.883 \mathrm{X}$ \\
\hline -Mineral oil & 329 & $(249.372-435.693)$ & 0.004 & 0.9 & $Y=-2.158+0.857 \mathrm{X}$ \\
\hline -Malathion & 36.04 & $(29.018-44.878)$ & 0.011 & 1.3 & $Y=-2.014+1.294 X$ \\
\hline
\end{tabular}

$\mathrm{CL}^{\mathrm{a}}: 95 \%$ Confidence Limits, $\mathrm{VL}^{\mathrm{b}}:$ Variance of slope, $\mathrm{S}^{\mathrm{c}}:$ Slope

Table 4. Toxicity rating and estimated risk phrases of the tested pesticides on $P$. subcapitata

\begin{tabular}{|c|c|c|}
\hline Pesticide & Fold of toxicity* & Risk phrase \\
\hline Carbendazim & Practically non-toxic & R52 \\
\hline Mineral oil & 1.2 & R52 \\
\hline Carbosulfan & 1.6 & $\mathrm{R} 52$ \\
\hline Thioallophanate-methyl & 4.9 & $\mathrm{R} 52 / 53$ \\
\hline Methomyl & 5.4 & $\mathrm{R} 52 / 53$ \\
\hline Dimethoate & 9.2 & $\mathrm{R} 52 / 53$ \\
\hline Malathion & 10.9 & $\mathrm{R} 52 / 53$ \\
\hline Fenamiphos & 20.9 & $\mathrm{R} 52 / 53$ \\
\hline Profenophos & 115.9 & R51/53 \\
\hline Imidaclopride & 144.9 & $\mathrm{R} 51 / 53$ \\
\hline Chlorpyrifos & 325 & $\mathrm{R} 51 / 53$ \\
\hline Chlorpyrifos-methyl & 391 & $\mathrm{R} 50 / 53$ \\
\hline Mancozeb+metalaxyl & 1441 & R50/53 \\
\hline Prochloraz & 1501 & $\mathrm{R} 50 / 53$ \\
\hline
\end{tabular}

* fold of toxicity is referred to the lowest toxicity value of carbendazim. all of the tested pesticides and found to be similar to those of the photosynthesis-inhibiting pesticides (Ma et al., 2002). Such data are also in accordance with other studies (Chronos, 2005; Elliott, 1998 and Pereira et al., 2009). From an ecological hazard point of view, both compounds can be classified as R51/53; i.e. very toxic to aquatic organisms and may cause long-term adverse effects in the aquatic environment. Similar results were obtained by Elliott, 1998 where mancozeb effectively suppressed development of blue-green algae. Some studies documented the inhibitory effect of prochloraz on P. subcapitata $\mathrm{P} 450$ monooxygenases (Thies et al., 1996; Sauser et al., 1998). Furthermore, Cedergreen et al., 2006 found that prochloraz does synergize the effect of some pesticides in the aquatic environment, but not consistently across species.
Other tested fungicides were found to have less ecological hazards as illustrated in Table (3\& 4) but thiallophanate-methyl showed 4.87 fold of toxicity than carbendazim. Few studies tested the toxicity of thiallophanate-methyl on algae but others found that the fungicide carbendazim may cause an increase of acute and chronic toxicity on fresh water organisms (Ferreira et al., 2008) and Scenedesmus obliqnus proved to be the more tolerant genera against many pesticides including carbendazim (Ma et al., 2002).

The toxicity and ecological risks of organophosphates (OPs) to algae displayed a wide range of variation depending on the chemical structure of compound and the tested species. Our data disclosed that $\mathrm{IC}_{50}$ values for chlorpyrifos and chlorpyrifos-methyl on $P$. subcapitata were close $(1.21$ and $1.01 \mathrm{mg} / \mathrm{L}$; 
respectively) and can be classified as ecological hazards (R50/53) that are very toxic to aquatic organisms and have long-term adverse effects. Toxicity rating analysis indicated that both compounds had 325 and 391 -fold of toxicity; respectively among the tested compounds. Our data are consistent with other studies (USEPA, 1989; EC Directive1107/2009) which supporting the evidence that chlorpyrifos and chlorpyrifos-methyl may represent hazards to the aquatic ecosystem due to their high acute toxicities, accumulation in the tissues of aquatic organisms and their persistence in sediments. Studies on phytotoxic effects of OPs on phytoplankton suggested that these toxicants can reduce growth rates, inhibit chlorophyll, protein, carbohydrate biosynthesis, photosynthetic carbon fixation and enhancement of respiratory oxygen consumption of planktonic algae after short- and long-term exposures (Macro et al., 1990; Mohapatra and Mohanty, 1992; Piska and Waghray, 1991; Mohapatra and Schiewer, 1996 and Mohapatra et al., 1997). Similarly, species such as Chlorella pyrenoidosa, Navicula pellicolosa, Anabaena and Aulosira fertilissima exhibited a significant decrease in the growth rate, photosynthesis, nitrogen fixation, nitrogenase activity and ${ }^{14} \mathrm{CO}_{2}$-uptake (Birmingham and Colman, 1977; Lal et al., 1987). However, other aquatic algae such as Chlamydomonas reinhardii showed an increase in growth when exposed to chlorpyrifos and in other situation, exposure to chlorpyrifos affected both survival and fecundity of several aquatic organisms with no effects on phytoplankton or physico-chemical parameters (Zalizniak and Nugegoda, 2006).

On the other hand, according to our risk analysis imposed on an aquatic ecosystem due to pesticide exposure, profenofos, fenamifos, malathion and dimethoate were found to cause less hazardous effects than caused by chlorpyrifos and chlorpyrifos-methyl. Such evidence is supported by the fact that diethyl phosphorothioates like diazinon, quinalphos and chlorfenvinphos were more toxic to green algae than dimethyl phosphorodithiotes like dimethoate and malathion (Wong and Chang, 1988). Profenofos was found to be the most hazardous (R51/53) and dimethoate was the least one (R52/53) among them. Acute toxicity of profenofos was more than 10 -folds the toxicity of malathion whereas, the toxicity of fenamifos was more than 2 -folds the toxicity of dimethoate. The results obtained herein are matching with other studies (PAN Pesticide Database, 2012; EXTOXNET, 2012).

As related to the potential ecological risks caused by carbamates, risk phrases were estimated for the 4 tested compounds. Risk resulting by mancozeb exposure was the highest than methomyl, carbosulfan and carbendazim as illustrated before. Similar differential responses of eight cyanobacteria and green algal species to five carbamate insecticides were reported (Ma et al., 2006; Pereira and Gonçalves, 2007) and the toxicity of these pollutants resulted in a shift from dominance by green algae to dominance by cyanobacteria and may sustain cyanobacterial blooms at particular times. There are, up to now, few reports describing the differential sensitivity of the green algae and cyanobacteria to different pollutants including pesticides.

Considering the nicotine-based systemic insecticides, toxicity rating of imidaclopride was 145 fold of toxicity and its risk phrase reported herein was R51/53 indicating a considerable aquatic ecosystem risk. Imidaclopride was known to have low risk of water contamination and a concentration of greater than 100 $\mathrm{mg} / \mathrm{L}$ for $72 \mathrm{hrs}$ was required to reduce the growth rate of the alga $P$. subcapitata by $50 \%$ (Tomlin, 2006; Tisler et al., 2009), however our data reported that the 96-h $\mathrm{IC}_{50}$ value of imidaclopride on the same organism was $2.714 \mathrm{mg} / \mathrm{L}$. Possible interactions between the pesticide and solvents could alter the toxicity of commercial preparation and only few toxicity studies have been performed on the effects of imidaclopride on aquatic organisms despite its increasing use (Jemec et al., 2007).

Furthermore, low risk of the tested mineral oil on aquatic ecosystem was reported in the current work (R53) and expected to cause long-term adverse effects on the aquatic environment. The 96-h $\mathrm{IC}_{50}$ value of Super Capl was $329 \mathrm{mg} / \mathrm{L}$. Comparatively; addition of whole crude oils to cultures of four test algae caused marked reduction in maximum specific growth rate and final yield in a concentration-dependent manner (Bate and Crafford, 1985). P. subcapitata was the most sensitive species and it was suggested that oils may affect photosynthetic metabolism in such organism.

Based on the magnitude of $\mathrm{IC}_{50}$ values, toxicity rating and estimated risk phrases, the decreasing order of the aquatic ecosystem risk was prochloraz > mancozeb+metalaxyl > chlorpyrifos-methyl > chlorpyrifos $>$ imidaclopride $>$ profenofos $>$ fenamifos $>$ malathion $>$ dimethoate $>$ methomyl $>$ thiallophanatemethyl > carbosulfan > mineral oil > carbendazim. Although toxicity data and risk estimations may show a strong association, low toxicity does not always imply low ecosystem risk under field conditions. This is may be attributed to the complexity of the aquatic ecosystem. Furthermore, these pollutants could imbalance the aquatic ecosystem since the pollutants may result in a shift of algal group structure, especially in a shift from dominance by green algae to dominance by cyanobacteria which can produce a variety of toxins including hepatotoxins such as microcystins and endotoxins such as lipopolysaccharides (Best et al., 
2002). Thus, the contamination could result in more ecosystem risk.

In conclusion, the results of this study clearly emphasize the importance of estimating risk phrases when assessing the pesticide stress on aquatic ecosystems and indicated that the tested pollutants may imbalance the aquatic ecosystem and cause a shift of algal species dominance. Such speculations need further more studies to fully understand the processes involved in pesticide toxicity.

\section{REFERENCES}

Bate, G.C. and Crafford, S.D. (1985). Inhibition of phytoplankton photosynthesis by the use of lubricating oil. Mar. Pollut. Bull., 16: 401-404.

Best, J.H.; Pflugmacher, S.; Wiegand, C.; Eddy, F.B.; Metcalf, J.S. and Codd, G.A. (2002). Effects of enteric bacterial and cyanobacterial lipopolysaccharides, and of microcystin-LR, on glutathione $S$ transferase activities in zebra fish (Danio rerio). Aquat. Toxicol., 60: 223-231.

Birmingham, B. and Colman B. (1977). The effect of two organophosphate insecticides on the growth of freshwater algae. Can. J. Bot., 55:1453-1456.

Brock, T.C.M.; Van Wijngaarden, R.P.A. and Van Geest, G.J., (2000). Ecological risks of pesticides in freshwater ecosystems. Part 2: Insecticides. Alterra Green World Research Report 089, Wageningen, Netherlands.

Cedergreen, N.; Kamperb, A. and Streibig, J. C. (2006). Is prochloraz a potent synergist across aquatic species? A study on bacteria, daphnia, algae and higher plants. Aquatic Toxicol., 78: 243-252.

Chronos 450 SC: Material Safety Data Sheet (2005). http://www.masa.co.za/images/stories /pdf/msds/chronos450Sc.pdf

Crossland, N.O. (1984). Fate and biological effects of methyl parathion in outdoor ponds and laboratory aquaria. II: Effects. Ecotoxicol. \& Environ. Safety, 8: 482-495.

EC Directive 1107 (2009). Chlorpyrifos-methyl: Environmental fate, Ecotoxicity and Human Health. http://sitem.herts.ac.uk/aeru/iupac/Reports/155.htm

Elliott, M.L. (1998). Use of fungicides to control blue-green algae on Bermuda grass putting green surfaces. Crop Protection, 7(8): 631-637.

European Union Directive 67/548/EEC (December, 2011): Nature of special risks attributed to dangerous substances and preparations. Annex III.

EXTOXNET (2012). Dimethoate. http://pmep.cce.cornell.edu/profiles/extoxnet/dienochlor_ glyphosate/dimethoate-ext.html.

Faust, M.; Altenburger, R.; Backhaus, T.; Bodeker, W.; Scholze, M. and Grimme, L.H. (2000). Ecological risk assessment: Predictive assessment of the aquatic toxicity of multiple chemical mixtures. J. Environ. Qual., 29: 1063-1067.
Ferrando, M. D.; Sancho, E. and Andreu-Moliner, E. (1996). Chronic toxicity of fenitrothion to an algae (Nannochloris oculata), a rotifer (Brachionus calyciflorus), and the cladoceran (Daphnia magna). Ecotoxicol.\& Environ. Safety, 35:112-120.

Ferreira, A. L.G.; Loureiro, S. and Soares, A. M.V.M. (2008): Toxicity prediction of binary combinations of cadmium, carbendazim and low dissolved oxygen on Daphnia magna. Aquatic Toxicol., 89: 28-39.

Finney, D.J. (1971). Probit analysis. Third Edition. Cambridge Press, New York, NY. pp.668.

Jemec, A.; Tišler, T.; Drobne, D.; Sepc `ic', K.; Fournier, D. and Trebše, P. (2007). Comparative

toxicity of imidacloprid, of its commercial liquid formulation and of diazion to a non-target arthropod, the microcrustacean Daphnia magna. Chemosphere, 68: 1408-1418.

Jonsson, C.M.; Maia, A.H.N.; Ferreira, C.J.A. and Ribeiro, E.O. (1998). Risk assessment of the herbicide clomazone on aquatic life. Verh. Int. Verein. Limnol., 26: 17241726.

Jonsson, C.M. and Maia, A.H.N. (1999). Protocolo de Avaliac,ão de Agentes Microbianos de Controle Biológico de Pragas para Registro como Biopesticidas. III. Testes em Organismos $\mathrm{Na}^{2} \mathrm{o}$ Alvo do Ambiente Aquático. Se'rie Documentos. Embrapa Meio Ambiente, Jaguariu'na. p33.

Lal, S.; Saxena, D. M. and Lal, R. (1987). Effects of DDT, fenitrothion and chlorpyrifos on growth, photosynthesis and nitrogen fixation in Anabaena (Arm 310) and Aulosira fertilissima. Agriculture Ecosyst. \& Environ., 19(3): 197-209.

Ma, J.; Zheng, R.; Xu, W. L. and Wangz, S. S. (2002). Differential sensitivity of two green algae, Scenedesmus obliqnus and Chlorella pyrenoidosa to12 Pesticides. Ecotoxicol. \& Environ. Safety, 52: 57- 61.

Ma, J.; Lin, F.; Qin, W. and Wang, P. (2004a). Differential response of four cyanobacterial and green algal species to triazophos, fentin acetate and ethephon. Bull. Environ. Contam. Toxicol., 73:890-897.

Ma, J; Lin, F.; Wang, S. and Xu, L. (2004b). Acute toxicity assessment of 20 herbicides to the green alga Scenedesmus quadricauda (Turp.) Breb. Bull. Environ. Contam. \& Toxicol.; 72:1164-71.

Ma, J.; Lua, N.; Qinb, W., Xua, R.; Wanga, Y. and Chena X. (2006). Differential responses of eight cyanobacterial and green algal species to carbamate insecticides. Ecotoxicol. \& Environ. Safety, 63: 268-274.

Macro, E.; Martinez, F. and Orus, M. I. (1990). Physiological alterations induced by the organophosphorus insecticide trichlorfon in Anabaena PCC7119 grown with nitrates. Environ. Exp. Bot., 30, 119-126.

Megharaj, M.; Singlenton, I.; Kookana, R. and Naidu, R. (1999). Persistence and effects of fenamiphos on native algal populations and enzymatic activities in soil. Soil Biol. Biochem., 31:1549-53. 
Miller, W.E.; Greene, J.C. and Shiroyama, T. (1978). The selenastrum capricornutumn algal assay bottle: Experimental design, application and data interpretation protocol. EPA-600/9-78-018, U.S. EPA, Corvallis, OR.

Mohapatra, P. K., and Mohanty, R. C. (1992). Growth pattern changes of Chlorella vulgaris and Anabaena doliolum due to toxicity of dimethoate and endosulfan. Bull. Environ. Contam. \& Toxicol., 49, 576-581.

Mohapatra, P. K. and Schiewer, U. (1996). Influence of dimethoate on structure and function of the natural phytoplankton assemblage of the Darss-Zingst bodden chain reared in a laboratory Pol. J. Environ. Stud., 5, 31 36.

Morales-Loo, M.R. and Goutx, M. (1990). Effects of watersoluble fraction of the Mexican crude oil "Isthmus Cactus" on growth, cellular content of chlorophyll a, and lipid composition of planktonic microalgae. Mar. Biol., 104: 503-509.

Moriarty, F. (1990). Ecotoxicology. The study of pollutants in ecosystems, $2^{\text {nd }}$ ed. Academic Press, Harcourt Brace Jovanovich, Publishers, London, San Diego, New York, Boston, Sydney, Toronto and Tokyo. p 289.

OECD (1984). Test Guideline 201 (Alga, Growth inhibition Test) Update draft, OECD, Paris, France.

OECD (July 2002). Test Guideline 201 (Freshwater Alga and Cyanobacteria, Growth inhibition Test) Update draft, OECD, Paris, France.

Okamura, H.; Mingyu, P.; Aoyama, I.; Sudo, M.; Okubo, T.; Nakamura, M. (2002). Algal growth inhibition by river water pollutants in the agricultural area around lake Biwa, Japan. Environ. Pollut., 117: 411-419.

PAN Pesticides Data (2012). Chemical Toxicity: Studies on Aquatic Organisms. http://www.pesticideinfo.org/list_AquireAll.jsp?Rec_Id=P C33349\&Taxa_group=Phytoplankton

Pereira, J. L. and Gonçalves, F. (2007). Effects of food availability on the acute and chronic toxicity of the insecticide methomyl to Daphnia spp. Science of the Total Environment, 386: 9-20.

Pereira J.L., et al (2009). Toxicity evaluation of three pesticides on non-target aquatic and soil organisms: commercial formulation versus active ingredient. Ecotoxicology, 18(4): 455-463.

Piska, R. S. and Waghray, S. (1991). Toxic effects of dimethoate on primary production of lake ecosystem. Indian J. Environ. Health, 33, 126-127.

Real, M.; Munoz, I.; Guasch, H.; Navarro, E.; Sabater, S. (2003). The effect of copper exposure on a simple aquatic food chain. Aquatic Toxicol., 63:283-291.

Sabater, C. and Carrasco, J.M. (2001). Effects of pyridaphenthion on growth of five freshwater species of phytoplankton: A laboratory study. Chemosphere, 44: 1775-1781.
Sand-Jensen, K. and Borum, J. (1991) Interactions among phytoplankton, periphyton, and macrophytesin temperate freshwaters and estuaries. Aquatic. Bot., 41:137-175.

Sauser, K.R.; Chung, K.T. and Wong, T.Y. (1998). Promutagen activation by the green alga; Selenastrum capricornutum. Environ. Toxicol. Chem., 17: 1825-1829.

Stampfli, N. C.; Knillmann,A.; Liess,M. and Beketov, M. A. (2011). Environmental context determines community sensitivity of freshwater zooplankton to a pesticide. Aquatic Toxicol., 104:116-124.

Thies, F.; Backhaus, T.; Bossmann, B. and Grimme, L.H. (1996). Xenobiotic biotransformation in unicellular green algae: Involvement of cytochrome P450 in the activation and selectivity of the pyridazinone pro-herbicide metflurazon. Plant Physiol., 112: 361-370.

Tišler, T.; Jemec, A.; Mozetic, B. and Trebše, P. (2009). Hazard identification of imidacloprid to aquatic environment. Chemosphere, 76: 907-914.

Tomlin, C.D.S. (2006). The Pesticide Manual, A World Compendium, $14^{\text {th }}$ ed.; British Crop Protection Council: Surry, England, pp: 598-599.

U.S. EPA (1989). Registration Standard (Second Round Review) for the Registration of Pesticide Products Containing Chlorpyrifos. Washington, DC, p.5-44.

U.S. EPA (1994). 96-hour Static Toxicity Test Using Selenastrum capricornutum. SOP\#: 2027. Environmental Protection Agency, Washington.

U.S. EPA (2002 updated). Green alga; Selenastrum capricornutum, Growth Test Method 1003.0. Environmental Research Laboratory, U.S.EPA, Corvallis, OR 97333, pp 197.

Van den Brink, P.J.; Van Donk, E.; Gylstra, R.; Crum, S. J. H. and Brock, T. C.M. (1995). Effects of chronic low concentrations of the pesticides chlorpyrifos and atrazine in indoor freshwater microcosms. Chemosphere, 31(5): 3181-3200.

Walsh, G.E. and Merril, R.G. (1984). Algal bioassays of industrial and energy process effluents. In: Shubert, L.E. (Ed.), Algae as Ecological Indicators. Academic Press, London, UK, pp. 329-360.

Weyers, A. and Vollmer, G. (2000). Algal growth inhibition: effect of the choice of growth rate or biomass as endpoint on the classification and labeling of new substances notified in the EU. Chemosphere, 41: 1007-1010.

Wong, P.K. and Chang, L. (1988). The effects of 2,4-D herbicide and organophosphorus insecticides on growth, photosynthesis, and chlorophyll a synthesis of Chlamydomonas reinhardtii. Environ. Pollution, 55: 179189.

Zalizniak, L. and Nugegoda, D. (2006). Effect of sublethal concentrations of chlorpyrifos on three successive generations of Daphnia carinata. Ecotox. \& Environ. Safety, 64: 207-214. 


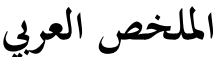

\section{المخاطر الأيكولوجية لبعض المبيدات على النباتات المائية: الثأثير على طحلب المياه العذبة الأخضر \\ Pseudokirchneriella subcapitata}

سلوي مصطفى عبدالله، نعمة عبدالرازق جودة، مديحة مُمحّم طلحة

mancozeb, methomyl, ) أمـا مركبـات الكرباميـت

(carbendazim, carbosulfan

النصف مميتة) 0.27 و6 72.9 و6 393.2 بجم/لتر على

التوالى).

وبنـاء على درجـات الخطرالمقـدرة- فـأن الترتيـب التنـازلى للخطر

المتمل على البيئة المائية والناتج عن المركبات المختبرة- كان كما يلى:

Prochloraz > mancozeb+metalaxyl > chlorpyrifosmethyl $>$ chlorpyrifos $>$ imidaclopride $>$ profenofos $>$ fenamifos > malathion > dimethoate > methomyl > thiallophanate-methyl $>$ carbosulfan $>$ mineral oil $>$ carbendazim.

وفن الخلاصة فأن نتائج هذه الدراسة تظهر بوضوح أهمية تقدير

درجات الخطر عند تقييم العبء البيئى للمبيدات على النظم المائية.

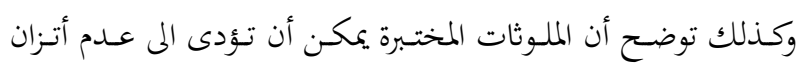

النظام البيئى المائى وتحدث تغييرا في أنواع الطحالب السائدة. وهذه النهات

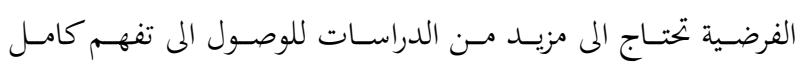
للعمليات المصاحبة لسمية المبيدات في البيئة المائية.
تمت دراسة سمية البيئة المائية والحساسية التفاضلية لبعض مجاميع

Pseudokirchneriella المبيدات على طحلب المياه العذبة الأخضر subcapitat

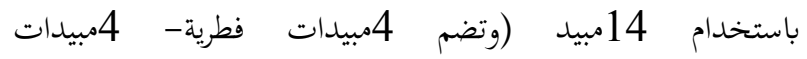
أكاروسية/نيماتودية- 6 مبيدات حشرية). وبناء على القيم النصف

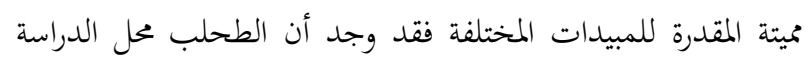
كان أكثر حساسية لعدة مبيدات(معظمها مبيدات فطرية وأكاروسية

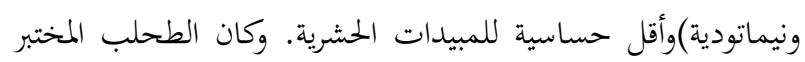
كان أكثر تحملا لمركب carbendazim في حين أنه كان شديد التأثر بمركب prochloraz . وقد سجلت القيم النصف مميتة بعد 96 ساعة

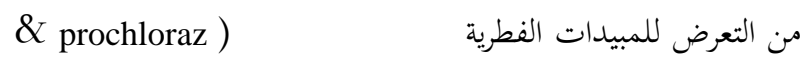
(thiallophanate-methyl قيم تتراوح بين 0.26 0.8 80.81

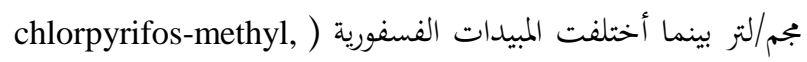
chlorpyrifos, profenofos, fenamifos, malathion (dimethoate, مجم/لتر. 